\title{
Anti-Alzheimer's Activity of Compounds from the Methanolic Extract of Lawsonia inermis Seeds: In vivo and in silico Molecular Docking Studies
}

\author{
Punabaka Jyothi, Kuna Yellamma* \\ Division of Neurobiology, Department of Zoology, Sri Venkateswara University, Tirupati, Andhra Pradesh, INDIA.
}

\begin{abstract}
Background: Alzheimer's disease (AD) hallmark feature is neurodegeneration due to the accumulation of $\beta$-amyloid plaques and the formation of neurofibrillary tangles in the aged brain. The prevalence of $A D$ in humans is doubled for every two decades and is expected to reach 74.7 million worldwide by 2030. Numerous treatment approaches for $A D$ are currently available but success rate is very limited, therefore novel medicines that minimize AD progression are urgently needed. Methods: In this study, in vivo experiments were performed to test the anti-Alzheimer's property of MELIS on male albino rats under $\mathrm{D}$-galactose induced AD. Estimation of ACh content and AChE activity in cerebral cortex was done in different groups of rats. In addition, in in silico analysis, molecular docking of MELIS compounds against AChE was performed in Auto dock vina software tool. Results: MELIS exhibited Anti-alzheimer's properties in rats by modulating ACh and AChE. Further, in silico molecular docking studies found top 10 MELIS compounds such as Dihydromyricetin, Quercitrin, Zearalenone, Leupeptin, Moricizinesulfone, Lecanoric acid, Sulfamerazine, 3-Deoxyguanosine, N-(3-indolylacetyl)-lisoleucine and Trimethoprim exhibited anti-acetylcholinesterase (AChE) property through showing good binding affinity by forming hydrogen bond interactions with active site amino acids. Conclusion: It is conclude from the results that MELIS compounds exhibit anti-Alzheimer property by modulating the ACh content, AChE activity and interacting to AChE active site amino acids. Therefore MELIS could be preferred source of active compounds for isolation and identification of new drugs for the $A D$ treatment.
\end{abstract}

Key words: Alzheimer's Disease, AChE, ACh, Cholinergic systems, Docking studies and Lawsonia inermis.

\section{INTRODUCTION}

Alzheimer's Disease (AD) is characterized by forfeiture in behavioural domains such as attention, perceptual and constructive skills, language, memory, orientation, functional skills and problem solving. ${ }^{1}$ Consequently, more than 15 million people are suffering globally from $\mathrm{AD}$ due to aging and hence medicinally their recovery becomes hard. ${ }^{2}$ Till now, AD patients have not been effectively treated but their life span had been increased by using certain drugs. ${ }^{3}$ The neuropathological features of the AD are formation of extracellular $\beta$ amyloid plaques and neurofibrillary intracellular tangles in the brain. ${ }^{4} \mathrm{~A}$ wide range of evidences indicate that the existence of many other pathological symptoms of different neurodegenerative diseases and aging are contributing for increased number of $\mathrm{AD}$ patients. ${ }^{5}$ Deficiency of a key neurotransmitter, viz. Acetylcholine (ACh), which transmits the signal between the neurons has been linked to $\mathrm{AD}$. Acetylcholine esterase (AChE), associated with the cholinergic transmission plays a vital role in depletion of acetylcholine through rapid hydrolysis. Hence, AChE is considered as a therapeutic target enzyme to develop cholinergic inhibitors to treat $\mathrm{AD} .^{6}$ Another reason for selecting $\mathrm{AChE}$ as target
Submission Date: 02-07-2020; Revision Date: 24-12-2020; Accepted Date: 13-03-2021

DOI: 10.5530/ijper.55.2.84 Correspondence: Prof. K Yellamma Department of Zoology, Sri Venkateswara University, Tirupati, Chittoor-517502, Andhra Pradesh, INDIA. Phone no: +919885248629 Email id: yellamma55@ gmail.com

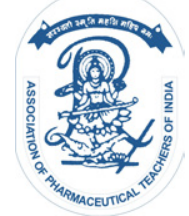

www.ijper.org 
is its association with other pathological features of $\mathrm{AD}$ such as $\beta$-amyloid precursor plaques and neurofibrillary tangles, which collectively induce a series of complex events in progression of $\mathrm{AD}^{7}$ Identification of novel inhibitors against $\mathrm{AChE}$ was started since a few decades by pharmacological companies and research institutions. The main reason for their failure in producing AChE inhibitors in animal models and cell lines are involvement of a huge expenditure, no reproducible results, time consuming, manpower. ${ }^{8}$ To overcome all these problems, a new stream of biology that bioinformatics, which deals with computer applications on biological molecules has been introduced. Structurebased virtual screening is a part of bioinformatics which explores the potential inhibitors from subset of millions of compounds stored in various databases against therapeutic target protein/enzymes of interest computationally within short period of time. ${ }^{9,10}$

As per report of the AD international 2015, neurodegenerative diseases are doubling for every two decades due to aging and dementia, which will recapture 74.7 million by 2030. Treatment for neurodegenerative disorder such as AD is currently very limited, new medications that reduce $\mathrm{AD}$ progression are urgently needed. Ethnopharmacological screening of natural plants against diseases are a primary step towards the production of new therapeutic medicines. ${ }^{11,12}$ Naturally available sources have been used to isolate FDA approved drugs such as Galantamine and Rivastigmine as anti-Alzheimeric agents for mild to moderate $\mathrm{AD}$ treatment. ${ }^{13}$

Selection and screening of inhibitors for any target is the most important aspect in structure- based virtual screening because resulted inhibitors will be used for further studies in animals. In this connection, selection of naturally available compounds of medicinal plant origin are good choice because they do not exert any adverse effects. ${ }^{14,15}$ On this basis, in the present study, we selected the compounds from medicinal plant, Lawsonia inermis, commonly known as Henna for screening against AChE. Henna has many medicinal properties such as anti-Pyretic, anti-Fertility, antiArthritic, anti-Cancer, anti-Tubercular, anti-Diabetic, anti-Inflammatory and anti-Alzheimers. ${ }^{16}$

\section{MATERIALS AND METHODS}

\section{Chemicals}

All the chemicals used in the present investigation were Analar grade (AR) and Solvents obtained from the following scientific companies: Sigma (USA), Fisher (USA), Merck (India), Himedia (India), TCI (China), Molychem (India) and SRL (India).

\section{Preparation of the plant extract}

Seeds of the plant, L. inermis, duly confirmed by a taxonomist Dr. Madhava Chetty, have been collected in Sri Venkateswara University campus, Tirupati and its surrounding areas. Initially, they were cleaned with tap water followed by distilled water. Seeds, dried under shade was powdered with scientific grinder, soaked in methanol (100\%), kept in dark for 3 days with occasional stirring using glass rod. After 3 days, the seed compounds dissolved in methanol were filtered orderly with muslin cloth, non-absorbent cotton and finally with what man No. 1 filter paper. The filtrate was further concentrated using rotary evaporator and the methanolic extract so obtained was preserved in refrigerator for further usage in various experiments.

\section{In vivo studies}

\section{Induction of Alzheimer's Disease}

The anti-AChE activity of MELIS was tested in three months old wistar strain male albino rats $(160 \pm 20)$ purchased from Sri venkateswara enterprises, Bangalore. For acclimatization, they were housed in cages in an animal house by maintaining $25-28^{\circ} \mathrm{C}$ temperature, $50-55 \%$ humidity and regular light/ dark condition for ten days. The experimental rats were fed with standard pellet diet and water ad libitum. The general health status of experimental rats during acclimatization was monitored every day. All the protocols followed in this study were approved by the ethical committee of Sri Venkateswara University (No.09 (i)/a/ CPCSEA/ IAEC/SVU/ZOOL/KY/ Dt. 08-07-2012).

\section{Grouping of animals}

Treatment : 60 days

Group I : (Normal control-NC): Rats received normal saline through oral gavage

Group II : (Disease control-DC): Rats received D-galactose $(120 \mathrm{mg} / \mathrm{kg})$ through intraperitoneal injection

Group III : (Plant control-PC) -Rats received only MELIS $150 \mathrm{mg} / \mathrm{kg}$ through oral gavage

Group IV : (Plant treatment-PT)- AD rats which received MELIS through oral gavage

\section{Tissue isolation}

For biochemical estimations, all rats of six groups were sacrificed on the $60^{\text {th }}$ day of treatment by cervical dislocation. The brain was isolated immediately and placed on a chilled glass plate. The selected brain region viz. cerebral cortex was separated by following standard anatomical protocol. ${ }^{17}$ Further, it was frozen in liquid nitrogen $\left(-180^{\circ} \mathrm{C}\right)$ and then stored at $-40^{\circ} \mathrm{C}$ until further 
use. At the time of biochemical analysis, the cerebral cortex tissue was thawed.

\section{Acetyl choline content}

ACh content in the cerebral cortex was estimated by the method of Metcalf (1951). ${ }^{18}$ Cerebral cortex was weighed accurately by using the scientific balance and transferred into test tubes, was placed in a boiling water bath for $5 \mathrm{~min}$ to terminate the AChE activity and also to release the bounded ACh. The tissue was homogenized in $1 \mathrm{ml}$ of distilled water. $1 \mathrm{ml}$ of alkaline hydroxylamine hydrochloride and $1 \mathrm{ml}$ of $50 \%$ hydrochloric acid solutions were added to the obtained homogenate. The contents were mixed thoroughly and centrifuged at $1000 \mathrm{rpm} / \mathrm{min}$. Supernatant was taken and $0.5 \mathrm{ml}$ of $0.37 \mathrm{M}$ ferric chloride was added. The resulted brown color was read in UV-Vis spectrophotometer at $540 \mathrm{~nm}$ against a blank (all contents where tissue homogenate was replaced with distilled water). The ACh content was expressed as $\mu$ moles of $\mathrm{ACh} / \mathrm{gm}$ wet weight of tissue.

\section{AChE Activity}

AChE activity was estimated by the Ellmans method (1961). ${ }^{19}$ 2\% (w/v) homogenate of cerebral cortex was prepared in $0.25 \mathrm{M}$ ice cold sucrose solution. To start the reaction, $100 \mu \mathrm{l}$ of homogenate was added to the reaction mixture containing $3 \mathrm{ml}$ of phosphate buffer ( $\mathrm{pH}$ 8.0), $20 \mu \mathrm{M}$ of substrate $(0.075 \mathrm{M})$ and $100 \mu \mathrm{M}$ of dithiobistrinitrobenzene (DTNB, 0.01M). The contents were incubated at $37^{\circ} \mathrm{C}$ for $15 \mathrm{~min}$. The resulted colour was read at $412 \mathrm{~nm}$ in a spectrophotometer against a reagent blank containing $3.0 \mathrm{ml}$ of phosphate buffer (pH 8.0), $20 \mu \mathrm{M}$ of substrate $(0.075 \mathrm{M})$ and $100 \mu \mathrm{M}$ of dithiobistrinitrobenzene (DTNB, $0.01 \mathrm{M}$ ). The enzyme activity was expressed as $\mu \mathrm{M}$ of $\mathrm{ACh}$ hydrolyzed/mg protein/hour.

\section{Statistical analysis}

All the experiments in triplicate were performed and the findings were expressed in mean $\pm S D$. One-way ANOVA has been used to test the significance of differences between experimental groups followed by multiple range tests by Tukey and Dunnet. SPSS.20v was used to conduct statistical analysis. The data at $p<0.05$ was regarded as a significant difference.

\section{In silico studies}

\section{Selection of therapeutic target protein}

Experimentally elucidated X-ray diffraction of AChE with resolution $2.697 \AA$ was downloaded from protein data bank (PDB). The PDB id for this structure is
5FPQ. ${ }^{20}$ This PDB structure was directly uploaded into protein preparation wizard of SPDB viewer to get optimized A chain along with energy minimization. All hetero atoms and water molecules present in the protein chain were deleted using Argus lab software. Further, partial charges were added to both the hetero groups and hydrogen atoms.

\section{Molecular docking studies}

3D coordinate of AChE was imported into auto dock vina software and converted it into pdbqt, a vina compatible format. All compounds, identified in MELIS by using HR-LC/Q-TOF/MS (see supplementary material Figure 1 and Table 1) were uploaded into auto dock vina wizard in a $2 \mathrm{D}$ format. All $2 \mathrm{D}$ co-ordinates, subjected to energy minimization were then converted into pdbqt format. Compounds and protein were simulated for docking according to genetic algorithm by setting up eight poses for each compound in the active site of protein. Among 8 poses, the pose which contains least energy with good binding affinity was selected for further analysis.

\section{Prediction of molecular properties}

Docking studies conducted on the top 10 compounds of MELIS have been subjected to Lipinski rule of 5 predictions such as molecular weight, cLogP, hydrogen bond donor count, hydrogen bond acceptor count using molinspiration. ${ }^{21}$ Also, the adverse effects of compounds such as mutagenicity, tumarogenicity, reproductive toxicity and irritant were measured with OSIRIS server. ${ }^{22}$

\section{RESULTS}

In AD-induced experimental rats, the ACh content in the cerebral cortex region of the brain was significantly decreased $(p<0.05)$ when compared with normal control rats (Figure 1). However, AD rats treated with MELIS for 60 days resulted in increment of ACh content. There were no significant changes observed in MELIS alone supplemented rats. On the contrary, the AChE activity was significantly $(p<0.05)$ increased in $\mathrm{AD}$ rats, whereas its activity was significantly decreased in AD rats treated with MELIS. No changes were observed in the AChE activity of both MELIS control rats and normal control rats.

Molecular docking studies explored the binding mode of MELIS compounds with active site amino acids of AChE, as follows: Table 1 represents the docking outcomes such as binding affinity, hydrogen bond interaction, bond distances and bond angles of top 


\begin{tabular}{|c|c|c|c|c|c|}
\hline S. No. & $\begin{array}{l}\text { Compound } \\
\text { Name and Pubchem ID }\end{array}$ & $\begin{array}{c}\text { Hydrogen } \\
\text { bonding }\end{array}$ & $\begin{array}{c}\text { BondDistance } \\
\text { (A) }\end{array}$ & $\begin{array}{c}\text { Bond } \\
\text { Angle }\left(^{\circ}\right)\end{array}$ & $\begin{array}{l}\text { Binding energy } \\
\text { (k cal/mole) }\end{array}$ \\
\hline 1 & $\begin{array}{l}\text { Dihydromyricetin } \\
\text { PC ID161557 }\end{array}$ & 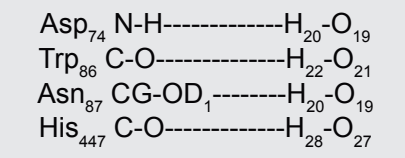 & $\begin{array}{l}2.2 \\
2.1 \\
2.4 \\
1.9\end{array}$ & $\begin{array}{l}123.3 \\
120.3 \\
168.0 \\
124.8\end{array}$ & -10.4 \\
\hline 2 & $\begin{array}{c}\text { Quercitrin } \\
\text { PC ID } 5280459\end{array}$ & 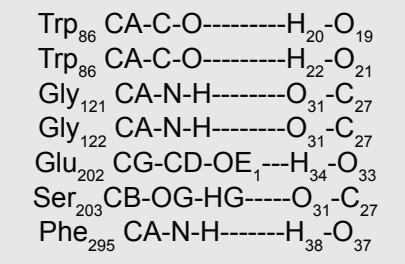 & $\begin{array}{l}2.2 \\
2.2 \\
2.3 \\
2.1 \\
2.6 \\
2.1 \\
2.1\end{array}$ & $\begin{array}{c}120.3 \\
93.5 \\
138.6 \\
124.4 \\
125.1 \\
131.0 \\
118.9\end{array}$ & -10.0 \\
\hline 3 & $\begin{array}{c}\text { Zearalenone } \\
\text { PC ID } 5281576\end{array}$ & $\operatorname{Trp}_{86} \mathrm{CA}-\mathrm{C}-\mathrm{O}-\mathrm{-}-\mathrm{-}_{24}-\mathrm{O}_{23}$ & 2.2 & 102.0 & -9.5 \\
\hline 4 & $\begin{array}{l}\text { Leupeptin } \\
\text { PC ID } 72429\end{array}$ & 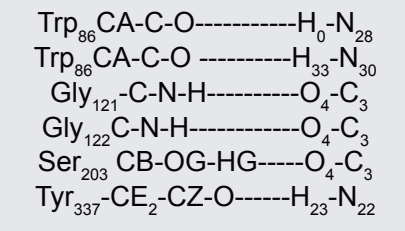 & $\begin{array}{l}2.0 \\
2.3 \\
2.7 \\
2.5 \\
2.6 \\
1.9\end{array}$ & $\begin{array}{l}110.0 \\
136.8 \\
121.2 \\
104.6 \\
135.1 \\
121.6\end{array}$ & -9.1 \\
\hline 5 & $\begin{array}{l}\text { Moricizinesulfone } \\
\text { PC ID } 3083448\end{array}$ & 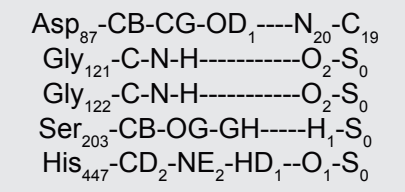 & $\begin{array}{l}3.5 \\
2.3 \\
2.8 \\
2.1 \\
2.5\end{array}$ & $\begin{array}{l}134.2 \\
105.5 \\
109.5 \\
140.0 \\
113.9\end{array}$ & -9.0 \\
\hline 6 & $\begin{array}{l}\text { Lecanoric acid } \\
\text { PC ID } 99613\end{array}$ & $\mathrm{Glu}_{202}-\mathrm{CG}-\mathrm{CD}-\mathrm{OE}_{2}---\mathrm{H}_{11}-\mathrm{O}_{10}$ & 1.8 & 106.9 & -9.0 \\
\hline 7 & $\begin{array}{l}\text { Sulfamerazine } \\
\text { PC ID } 5325\end{array}$ & $\begin{array}{l}\mathrm{Tyr}_{72} \mathrm{CA}-\mathrm{C}-\mathrm{O}-\mathrm{-}------\mathrm{H}_{21}-\mathrm{N}_{20} \\
\mathrm{Asn}_{87}-\mathrm{CB}-\mathrm{C}-\mathrm{OD}_{1}-----\mathrm{H}_{22}-\mathrm{N}_{20} \\
\mathrm{Tyr}_{337} \mathrm{CE}_{2}-\mathrm{CZ}-\mathrm{O}-------\mathrm{H}_{1}-\mathrm{N}_{5}\end{array}$ & $\begin{array}{l}2.1 \\
1.9 \\
1.9\end{array}$ & $\begin{array}{l}147.3 \\
145.7 \\
103.4\end{array}$ & -8.9 \\
\hline 8 & $\begin{array}{l}\text { 3-Deoxyguanosine } \\
\text { PC ID } 165138\end{array}$ & 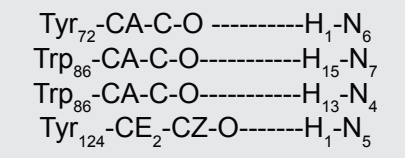 & $\begin{array}{l}2.4 \\
2.3 \\
2.6 \\
2.3\end{array}$ & $\begin{array}{l}135.5 \\
123.3 \\
109.4 \\
138.3\end{array}$ & -8.9 \\
\hline 9 & $\begin{array}{l}\text { N-(3-Indolylacetyl)- } \\
\text { Lisoleucine } \\
\text { PC ID } 644226\end{array}$ & $\mathrm{Tyr}_{337}-\mathrm{CE}_{1}-\mathrm{CZ}-\mathrm{O}------\mathrm{H}_{3}-\mathrm{N}_{1}$ & 2.3 & 109.5 & -8.8 \\
\hline 10 & $\begin{array}{l}\text { Trimethoprim } \\
\text { PC ID } 5578\end{array}$ & 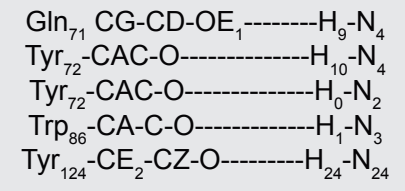 & $\begin{array}{l}2.6 \\
2.0 \\
2.3 \\
2.1 \\
2.1\end{array}$ & $\begin{array}{l}136.8 \\
109.4 \\
124.7 \\
119.1 \\
97.4\end{array}$ & -8.4 \\
\hline 11 & $\begin{array}{c}\text { Galantamine (Standard) } \\
\text { PC ID } 9651\end{array}$ & 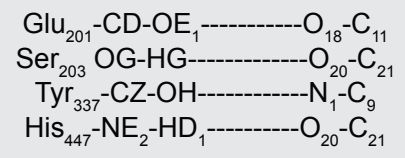 & $\begin{array}{l}2.6 \\
2.2 \\
2.9 \\
2.7\end{array}$ & $\begin{array}{l}145.1 \\
124.9 \\
139.3 \\
124.4\end{array}$ & -10.0 \\
\hline
\end{tabular}


ten compounds of MELIS with AChE protein. The docking interaction visualizations of all compounds with AChE were represented in Figure 2.

Ithas been predicted that the Dihydromyricetin compound exhibited good binding affinity (-10.4 kcal/mole) among all docked compounds in the active site of AChE. The complex, Dihydromyricetin and AChE showed that the ligand molecule interacted with $\mathrm{His}_{447}, \operatorname{Trp}_{80}, \mathrm{Asn}_{87}$ and $\mathrm{Asp}_{74}$ through hydrogen bond interaction. Another atom $\mathrm{H}_{20}$ of Dihydromyricetin was formed hydrogen bond with hydrogen atom of $\mathrm{His}_{447}$ amino acid. It was also noted that $\mathrm{H}_{22}$ atom of compound formed another hydrogen bond interaction with Oxygen atom of $\operatorname{Trp}_{86}$. $\mathrm{OD}_{1}$ atom of $\mathrm{Asn}_{87}$ was formed hydrogen bond with $\mathrm{H}_{20}$ atom of compound. $\mathrm{HIS}_{447}$ showed hydrogen bond interaction with $\mathrm{H}_{28}$ atom of compound. The bond angles and distances of the above said interaction were represented in Table 2.

After Dihydromyricetin, Quercitrin was shown to have $-10.0 \mathrm{kcal} / \mathrm{mole}$ binding affinity to AChE 's active site amino acids and occupied second place. Two atoms $\mathrm{H}_{20}$ and $\mathrm{H}_{22}$ of Quercitrin were interacted with $\mathrm{H}$ of $\operatorname{Trp}_{86}$. Two amino acids such as Gly ${ }_{121}$ and $\mathrm{Gly}_{122}$ were interacted with $\mathrm{O}_{31}$ atom of compound by hydrogen bond. $\mathrm{H}$ atom of compound got interacted with $\mathrm{OE}_{1}$ of
$\mathrm{Glu}_{202} . \mathrm{O}_{31}$ atom of compound acted as hydrogen bond donor and it formed bond with $\mathrm{H}$ of of $\mathrm{Ser}_{203}$. Finally, $\mathrm{H}$ atom of $\mathrm{Phe}_{295}$ interacted with $\mathrm{H}_{38}$ of compound. Similarly, Zearalenone compound exhibited binding affinity score $-9.5 \mathrm{kcal} /$ mole with single hydrogen bond interaction. This interaction formed in between $\mathrm{O}$ atom of $\operatorname{Trp}_{86}$ and $\mathrm{H}_{24}$ of compound. Next to this compound, Leupeptin exhibited binding affinity $-9.1 \mathrm{kcal} /$ mole with the active site of the AChE through six hydrogen bond interactions. They include $\mathrm{O}$ atom of $\operatorname{Trp}_{86}$ formed two hydrogen bond interactions with the $\mathrm{H}_{0}$ and $\mathrm{H}_{33}$. $\mathrm{O}_{4}$ of Leupeptin formed two hydrogen bond interactions with the $\mathrm{H}$ atoms of $\mathrm{Gly}_{121}$ and $\mathrm{Gly}_{122}$ of protein. Besides, gama $\mathrm{H}$ of $\mathrm{Ser}_{203}$ amino acid interacted with $\mathrm{O}_{4}$ of compound. Finally, $\mathrm{O}$ atom of $\mathrm{Tyr}_{337}$ exhibited hydrogen bond interaction with $\mathrm{H}_{23}$ atom of compound.

Another top fifth compound, Moricizinesulfone was showed binding affinity $-9.0 \mathrm{kcal} /$ mole. Compound was unveiled five hydrogen bond interactions with active site amino acids of protein. $\mathrm{OD}_{1}$ of $\mathrm{Asp}_{87}$ amino acid made a hydrogen bond interaction with $\mathrm{N}_{20}$ atom of compound. Also amino acids $\mathrm{Gly}_{121}$ and $\mathrm{Gly}_{122}$ interacted with same atom that oxygen of compound. Next, gama hydrogen of $\mathrm{Ser}_{203}$ showed interaction with

Table 2: Prediction of lipinski rule of five and adverse effects of compounds of MELIS (MW: Molecular weight; HBA: hydrogen bond acceptor; HBD: hydrogen bond donor; Mut: mutagenicity; Tum: tumorigenesis; Rep Tox: reproductive toxicity; Irri: irritant)

\begin{tabular}{|c|c|c|c|c|c|c|c|c|c|}
\hline S.No. & Compound & MW (g/mol) & cLogP & HBA & HBD & Mut & Tum & Rep Tox & Irri \\
\hline 1 & $\begin{array}{l}\text { Dihydromyricetin } \\
\text { PC ID161557 }\end{array}$ & 320.25 & 0.6122 & 8 & 6 & None & None & None & None \\
\hline 2 & $\begin{array}{c}\text { Quercitrin } \\
\text { PC ID } 5280459\end{array}$ & 448.379 & 0.5798 & 11 & 7 & None & None & None & None \\
\hline 3 & $\begin{array}{c}\text { Zearalenone } \\
\text { PC ID } 5281576\end{array}$ & 318.368 & 3.888 & 5 & 2 & None & None & None & None \\
\hline 4 & $\begin{array}{l}\text { Leupeptin } \\
\text { PC ID } 72429\end{array}$ & 426.560 & -0.4337 & 10 & 5 & None & None & None & None \\
\hline 5 & $\begin{array}{l}\text { Moricizinesulfone } \\
\text { PC ID } 3083448\end{array}$ & 459.522 & 2.3847 & 9 & 1 & None & None & High & None \\
\hline 6 & $\begin{array}{l}\text { Lecanoric acid } \\
\text { PC ID } 99613\end{array}$ & 318.280 & 2.2259 & 7 & 4 & None & None & None & None \\
\hline 7 & $\begin{array}{l}\text { Sulfamerazine } \\
\text { PMD ID } 5325\end{array}$ & 264.308 & 0.4856 & 6 & 2 & None & None & High & None \\
\hline 8 & $\begin{array}{l}\text { 3-Deoxyguanosine } \\
\text { PC ID } 165138\end{array}$ & 267.244 & -1.9543 & 9 & 4 & None & None & None & None \\
\hline 9 & $\begin{array}{c}\text { N-(3-Indolylacetyl)- } \\
\text { Lisoleucine } \\
\text { PC ID } 644226\end{array}$ & 288.346 & 1.7523 & 5 & 3 & None & None & None & None \\
\hline 10 & $\begin{array}{l}\text { Trimethoprim } \\
\text { PC ID } 5578\end{array}$ & 290.322 & 1.0686 & 7 & 2 & None & None & None & None \\
\hline 11 & $\begin{array}{c}\text { Galantamine (Standard) } \\
\text { PC ID } 9651\end{array}$ & 287.358 & 1.1901 & 4 & 1 & None & None & None & None \\
\hline
\end{tabular}


$\mathrm{H}_{1}$ of compound. $\mathrm{HD}_{1}$ of $\mathrm{His}_{447}$ amino acid formed hydrogen bond interaction with $\mathrm{O}_{1}$ of compound.

With regard to Lecanoric acid, it exhibited binding affinity $-9.0 \mathrm{kcal} / \mathrm{mole}$ with single hydrogen bond interaction. Amino acid $\mathrm{Glu}_{202}$ only formed the hydrogen bond interaction with $\mathrm{H}_{11}$ atom of compound. Next in the order was Sulfamerazine, which showed the binding affinity $-8.9 \mathrm{kcal} / \mathrm{mole}$. $\mathrm{Tyr}_{72}$ amino acid interacted with $\mathrm{H}_{21}$ atom of compound by giving hydrogen bond donor in the form of $\mathrm{O}$ atom. $\mathrm{OD}_{1}$ of $\mathrm{Asn}_{87}$ interacted with $\mathrm{H}_{22}$ of compound whereas $\mathrm{O}$ atom of $\mathrm{Tyr}_{337}$ showed bonding with $\mathrm{H}_{1}$ of compound. Further, 3-Deoxyguanosine also exhibited binding affinity $-8.9 \mathrm{kcal} / \mathrm{mole}$ with active site of AChE protein. $\mathrm{Tyr}_{72}$ amino acid interacted with $\mathrm{H}_{1}$ of compound. Oxygen of $\operatorname{Trp}_{86}$ formed 2 hydrogen bonds with $\mathrm{H}_{13}$ and $\mathrm{H}_{15}$ of compound. Fourth hydrogen bond formed in between oxygen atom of $\mathrm{Tyr}_{124}$ and $\mathrm{H}_{1}$ of 3-Deoxyguanosine.

Following the above, the compound, N-(3-Indolylacetyl)Lisoleucine exhibited $-8.8 \mathrm{kcal} /$ mole binding affinity by forming single hydrogen bond interaction. $\mathrm{Tyr}_{337}$ was
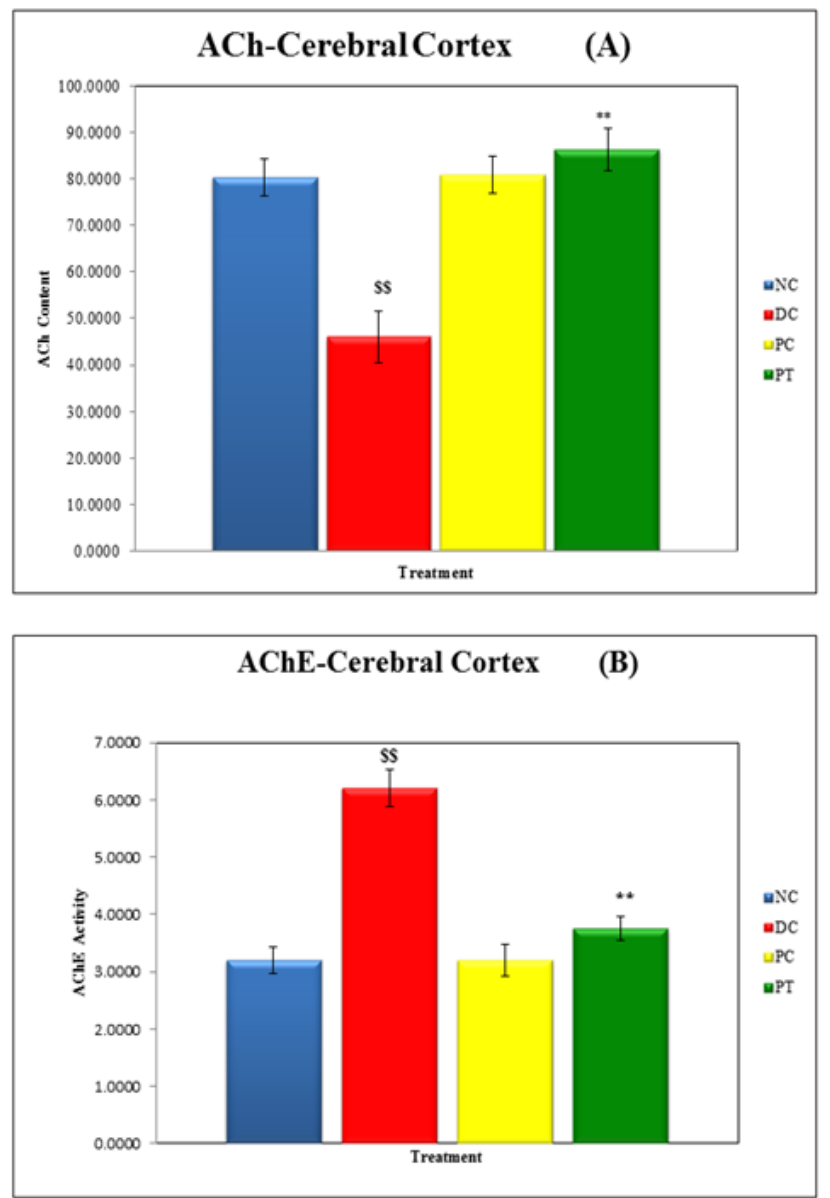

Figure 1: Effect of MELIS on ACh content $(A)$ and AChE activity $(B)$ in cerebral cortex region of $A D$-induced rats Brain. involved in hydrogen bond interaction with $\mathrm{H}_{3}$ atom of compound. Finally, Trimethoprim compound also showed $-8.4 \mathrm{kcal} /$ mole binding affinity score which was least among all above mentioned compounds. It was interacted to 4 amino acids with 5 hydrogen bonding interactions which include $\mathrm{OE}_{1}$ atom of $\mathrm{Gln}_{71}$ formed hydrogen bonding with $\mathrm{H}_{9}$ of compound. Oxygen atom of $\mathrm{Tyr}_{72}$ formed two hydrogen bond interactions with $\mathrm{H}_{0}$ and $\mathrm{H}_{10}$ atoms of compound. $\mathrm{H}_{1}$ of compound interacted with oxygen atom of $\operatorname{Trp}_{86}$. At end, $\mathrm{H}_{24}$ atom of Trimethoprim exhibited bonding with $\mathrm{Tyr}_{124}$ amino acid.

Molecular property prediction of MELIS compounds revealed that all compounds were qualified Lipinski rule of five. Further, these compounds also not showed any adverse effects except the two viz. Sulfamerazine and Moricizinesulfone which exhibited reproductive toxicity.

\section{DISCUSSION}

In the present study, we have screened the antiAlzheimer's properties of the compounds from MELIS against D-galactose induced $\mathrm{AD}$. The observations revealed that MELIS has significantly increased the ACh content in the cerebral cortex region of rat

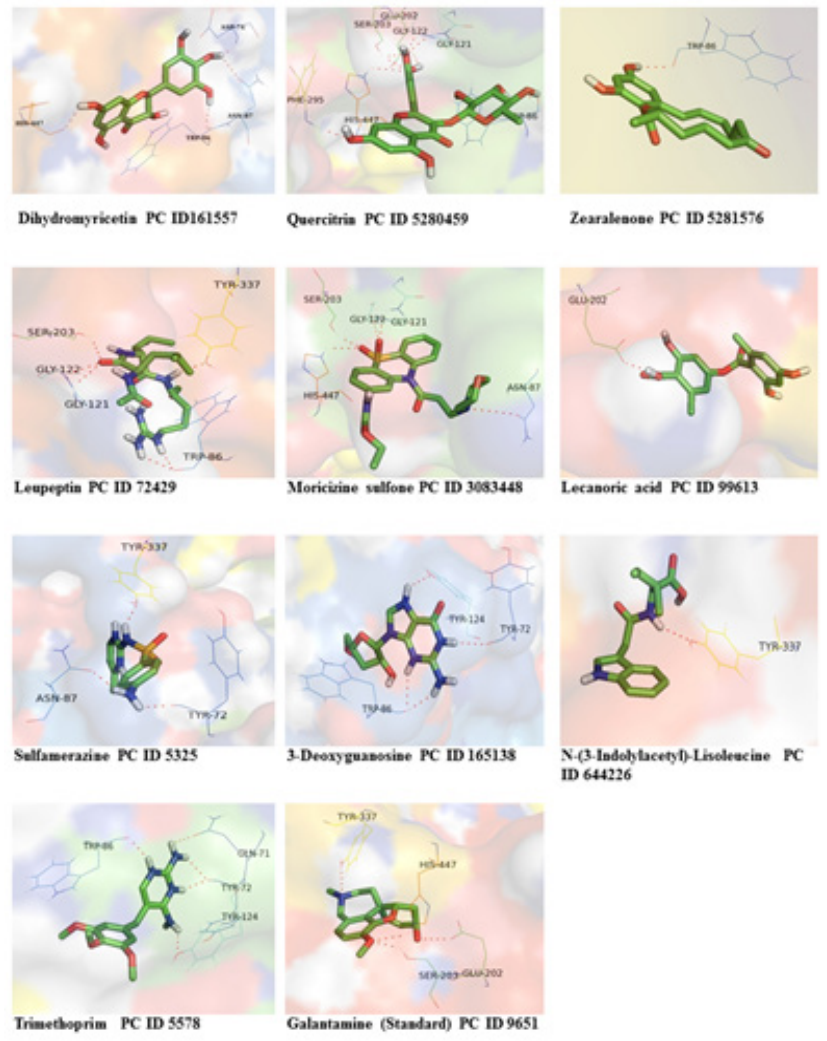

Figure 2: Molecular interactions of MELIS in active site of AChE where thick sticks denote compounds of MELIS whereas thin sticks denote interacted amino acids of AChE. 
brain under AD-induced conditions. Additionally, MELIS also decreased the activity levels of AChE in $\mathrm{AD}$ rats. $\mathrm{AChE}$ is a vital enzyme involved in rapid hydrolysis of neurotransmitter ACh in the central and peripheral nervous system. Increased AChE activity reduces the content of ACh which causes cognitive deficits. ${ }^{23}$ Recent findings have revealed that AChE is also involved in non-cholinergic mechanism intricate in neurodegeneration. Amyloid $\beta$ peptide aggregation has been accelerated by increasing AChE activity which results in neurodegeneration. ${ }^{24}$ In view of these observations, it is therefore inferred that, MELIS prevented neurodegeneration and amyloid beta plaques formation in cerebral cortex by inhibiting AChE activity. Further, persistent amount of ACh was also observed in MELIS-treated AD rats due to inhibition of $\mathrm{AChE}$, which improves the neuronal transmission.

One of biological streams such as bioinformatics helps scientists to identify new potential drugs against therapeutic targets of diseases with low-cost, effective and least man power. In the present study, we performed molecular docking studies against AChE protein with MELIS compounds. The structural elucidation of AChE revealed that it has $20 \AA$ deep active site gorge. ${ }^{25}$ The catalytic site present at the gorge's base having amino acids $\mathrm{His}_{447}, \mathrm{Glu}_{334}$ and $\mathrm{Ser}_{203}$ called catalytic triad. Along with that, a second site is also present at peripheral region extending beyond $\mathrm{Tyr}_{337}$ at the catalytic/peripheral site edge to the entrance of the gorge with numerous aromatic side chains. Kinetic and thermodynamic studies have demonstrated that inhibitors can interfere with either or both of the two AChE binding sites. ${ }^{26}$ In the present study, Quercitrin, Leupeptin and Moricizinesulfone have formed hydrogen bond interaction with $\mathrm{Ser}_{203}$ of AChE. It is very clear that these compounds would inhibit AChE activity through this hydrogen bond interaction with $\mathrm{Ser}_{203}$, one of the traid. Interestingly, a potential AChE inhibitor Galantamine was also bound to the same active site through four hydrogen bond interactions with $\mathrm{Glu}_{201}$, $\mathrm{Ser}_{203}, \mathrm{Tyr}_{337}$ and $\mathrm{His}_{447}$ amino acids. ${ }^{27}$ Similarly, MELIS compounds such as Leupeptin, Sulfamerazine, N-(3Indolylacetyl)-Lisoleucine were formed hydrogen bond interaction with $\mathrm{Tyr}_{337}$ as like Galantamine. Additionally, Dihydromyricetin and Moricizinesulfone were showed hydrogen bond interaction with $\mathrm{His}_{447}$ as Galantamine. An interesting aspect to note here is that though Dihydromyricetin and Galantamine bound in the same active site with hydrogen bond interactions with same amino acids, binding affinity rank of Dihydromyricetin (-10.4 kcal/mole) occupied much greater position than Galantamine $(-10.0 \mathrm{kcal} / \mathrm{mole})$. Therefore,
Dihydromyricetin could be considered as a good AChE inhibitor than Galantamine. This derives a strong support from a recent study wherein Dihydromyricetin was reported as anti-Alzheimer's agent in AD induced rats. ${ }^{28}$ Another study revealed that (-)-Huperzine A, also an AChE inhibitor shows its inhibitory activity by forming hydrogen bond interaction with $\mathrm{Tyr}_{133}$ and $\mathrm{Tyr}_{337}$, also hydrophobic interaction with $\operatorname{Trp}_{86}$ amino acid. ${ }^{27}$ In our docking results, interestingly, MELIS compounds viz. Dihydromyricetin, Leupeptin, 3-Deoxyguanosine and $\mathrm{N}$-(3-Indolylacetyl)-lisoleucine have formed hydrogen bond interaction with $\operatorname{Trp}_{86}$ similar to (-)-Huperzine A. This observation further lend support to the AChE inhibitory activity of MELIS compounds. Along with these important hydrogen bond interactions, many compounds of henna have formed hydrogen bond interaction with other active site amino acids of $\mathrm{AChE}$ which increase the inhibitory potentiality of these compounds thus clearly stating that MELIS contained compounds which act as AChE inhibitors by binding to the active site amino acids.

In the current results, all compounds screened were fulfilled the lipinski rule of five except Moricizinesulfone and Sulfamerazine, hence these compounds might be supplemented through non-oral manner. Lipinski et al. $(1997)^{29}$ predicted the chemical descriptors for FDA approved oral drugs and finally they found that they contained molecular weight $<500$, hydrogen bond donors $<5$, hydrogen bond acceptor $<10$ and octanol water partition coefficient (clog P) $<5$. Non-oral drugs,violating the lipinski rule of five indicate that drugs which follow this rule can be used through orally. ${ }^{30,31}$ Any drug which is prescribed for the treatment, they should not contain adverse effects like mutagenicity, tumarogenicity, reproductive effect and irritant. In our study, most of the compounds not exhibited any adverse effects except Sulfamerazine and Moricizinesulfone with reproductive toxicity. Here are clear evidences in the present investigation that the best ranked compounds might be the reason for the $\mathrm{AChE}$ inhibition in D-gal induced $\mathrm{AD}$ in in vivo.

\section{CONCLUSION}

Based on the findings of this study, it is conclude that MELIS exhibits anti-alzheimer activity in in vivo by modulating the content of ACh and AChE activity. In silico molecular docking studies revealed that among 63 compounds of MELIS, Dihydromyricetin, Quercitrin, Zearalenone, Leupeptin, Moricizinesulfone, Lecanoric acid, Sulfamerazine, 3-Deoxyguanosine, N-(3Indolylacetyl)-Lisoleucine and Trimethoprim acted as 
AChE inhibitors by showing good binding affinity with active site amino acids of AChE. It is therefore evidence that possible regulation of AChE by MELIS in both in vivo and in silico could be the choice to take MELIS as the key source of isolation for new and innovative drug compounds.

\section{ACKNOWLEDGEMENT}

Authors express sincere gratitude to the University Grants Commission New Delhi, India for the financial assistance to the Punabaka Jyothi in the form of RGNF (No: F1-17.1/2015-16/RGNF-2015-17-SCAND-17449).

\section{CONFLICT OF INTEREST}

Authors declare that there is no conflict of interest

\section{ABBREVIATIONS}

MELIS: Methanolic Extract of Lawsonia inermis; AD: Alzheimer's Disease; AChE: Acetylcholinesterase; ACh: Acetylcholine; DTNB: Dithiobistrinitrobenzene; PDB: Protein Data Bank; HR-LC/Q-TOF/MS: High Resolution-Liquid Chromatography/Quadrupole Timeof-Flight/ Mass Spectrometer; FDA: Food and Drug Administration.

\section{REFERENCES}

1. Amari NO, Djebli N, Huong LM, Hong TTH, Luyen GD, Bich VT. Neuroprotective effect of 1,3- $\beta$-glucan-curcumin mixing (Bioglucur) on Alzheimer Disease Induced in Mice by Aluminium Toxicity. Indian J of Pharmaceutical Education and Research. 2020;54(4):1089-97.

2. Franceschi C, Garagnani P, Morsiani C, Conte M, Santoro A, Grignolio A, et al. The Continuum of Aging and Age-Related Diseases: Common Mechanisms but Different Rates. Front Med. 2018;5:61.

3. Khaligh-Razavi SM, Habibi S, Sadeghi M, Marefat H, Khanbagi M, Nabavi $\mathrm{SM}$, et al. Integrated Cognitive Assessment: Speed and Accuracy of Visual Processing as a Reliable Proxy to Cognitive Performance. Sci Rep. 2019;9(1):1102.

4. Kumar A, Singh AE. A review on Alzheimer's disease pathophysiology and its management: An update. Pharmacol Rep. 2015;67(2):195-203.

5. Wojsiat J, Zoltowska KM, Laskowska-Kaszub K, Wojda U. Oxidant/ Antioxidant Imbalance in Alzheimer's Disease: Therapeutic and Diagnostic Prospects. Oxid Med Cell Longev. 2018;6435861.

6. Tabet N. Acetylcholinesterase inhibitors for Alzheimer's disease: antiinflammatories in acetylcholine clothing!. Age Ageing. 2006;35(4):336-8.

7. García-Ayllón MS, Small DH, Avila J, Sáez-Valero J. Revisiting the Role of Acetylcholinesterase in Alzheimer's Disease: Cross-Talk with P-tau and ß-Amyloid. Front Mol Neurosci. 2011;4:22.

8. Jyothi P, Yellamma K. Molecular Docking Studies on the Therapeutic Targets of Alzheimer's disease (AChE and BChE) using Natural Bioactive Alkaloids. Int J Pharm Pharmsci. 2016;8(12):108-12.

9. Ortega SS, Cara LC, Salvador MK. In silico pharmacology for a multidisciplinary drug discovery process. Drug Metabol Drug Interact. 2012;27(4):199-207.
10. Chen L, Morrow JK, Tran HT, Phatak SS, Du-Cuny L, Zhang S. From laptop to benchtop to bedside: Structure-based drug design on protein targets. Curr Pharm Des. 2012;18(9):1217-39.

11. Nwidu LL, Elmorsy E, Thornton J, Wijamunige B, Wijesekara A, Tarbox R, et al. Anti-acetylcholinesterase activity and antioxidant properties of extracts and fractions of Carpolobia lutea. Pharm Biol. 2017;55(1):1875-83.

12. Ravi S, Shanmugam B, Subbaiah GV, Prasad SH, Reddy KS. Identification of food preservative, stress relief compounds by GC-MS and HR-LC/Q-TOF/ MS: Evaluation of antioxidant activity of Acalypha indica leaves methanolic extract (in vitro) and polyphenolic fraction (in vivo). J Food Sci Technol. 2017;54(6):1585-96

13. Syad AN, Devi KP. Botanics: A potential source of new therapies for Alzheimer's disease. Botanics: Targets Therapy. 2014;4:11-26.

14. Cvetanović A, Zengin G, Zeković Z, Švarc-Gajić J, Ražić S, Damjanović A, et al. Comparative in vitro studies of the biological potential and chemical composition of stems, leaves and berries Aronia melanocarpa's extracts obtained by subcritical water extraction. Food Chem Toxicol. 2018;121:45866.

15. Sahukari R, Punabaka J, Bhasha S, Ganjikunta VS, Ramudu SK, Kesireddy SR. Plant Compounds for the Treatment of Diabetes, a Metabolic Disorder: NF-KB as a Therapeutic Target. Curr Pharm Des. 2020;26(39):4955-69.

16. Zümrütdal E, Ozaslan M. A Miracle Plant for the Herbal Pharmacy; Henna (Lawsonia inermis). International Journal of Pharmacology. 2012;8(6):483-9.

17. Glowinski J, Iverson LL. Regional studies of catecholamine's in the rat brain. I. The disposition of $(3 \mathrm{H})$ norepinephrine, $(3 \mathrm{H})$ dopamine and $(3 \mathrm{H})$ dopa in various regions of the brain. Journal of Neurochemistry. 1966;13:655-69.

18. Metcalf RL. In Methods of Biochemical Analysis. Newyark: Interscience Publishers Inc; 1957.

19. Ellman GL, Courtney DK, Andreas V, Featherstone RM. A new and rapid colorimetric determination of acetylcholinesterase activity. Biochem Pharmacol. 1961;7:88-95.

20. https://www.rcsb.org

21. www.molinspiration.com

22. www.organic-chemistry.org/prog/peo/.

23. Ferreira-Vieira TH, Guimaraes IM, Silva FR, Ribeiro FM. Alzheimer's disease: Targeting the Cholinergic System. Curr Neuropharmacol. 2016;14(1):101-15.

24. Atali S, Dorandish S, Devos J, Williams A, Price D, Taylor J, et al. Interaction of amyloid beta with humanin and acetylcholinesterase is modulated by ATP. FEBS Open Bio. 2020;10(12):2805-23.

25. Sussman JL, Harel M, Frolow F, Oefner C, Goldman A, Toker L, et al. Atomic structure of acetylcholinesterase from Torpedo californica: A prototypic acetylcholine-binding protein. Science. 1991;253(5022):872-9.

26. Rosenberry TL, Sonoda LK, Dekat SE, Cusack B, Johnson JL. Monitoring the reaction of carbachol with acetylcholinesterase by thioflavin $\mathrm{T}$ fluorescence and acetylthiocholine hydrolysis. Chem Biol Interact. 2008;175(1-3):235-41.

27. Cheung J, Rudolph MJ, Burshteyn F, Cassidy MS, Gary EN, Love J, et al. Structures of human acetylcholinesterase in complex with pharmacologically important ligands. J Med Chem. 2012;55(22):10282-6.

28. Sun P, Yin JB, Liu LH, Guo J, Wang SH, Qu CH, et al. Protective role of Dihydromyricetin in Alzheimer's disease rat model associated with activating AMPK/SIRT1 signaling pathway. Biosci Rep. 2019;39(1):BSR20180902.

29. Lipinski CA, Lombardo F, Dominy BW, Feeney PJ. Experimental and computational approaches to estimate solubility and permeability in drug discovery and development settings. Adv Drug Deliv Rev. 2001;46(1-3):3-26.

30. Choy YB, Prausnitz MR. The rule of five for non-oral routes of drug delivery: Ophthalmic, inhalation and transdermal. Pharm Res. 2011;28(5):943-8.

31. Ravi S, Jyothi P, Lakshmi R, Shanmugam B, Subbaiah GV, Reddy KS. Identification of Anticancer Lead Molecules against PRR11 Protein Target with Combination of Protein Modelling Through Threading Approach, Structure Based Chemical Screening of ZINC Database and Pharmacokinetic Properties. Indian J of Pharmaceutical Education and Research. 2018;52(3):381-8. 


\begin{tabular}{|c|c|c|c|c|}
\hline S.No & $\begin{array}{l}\text { Retention } \\
\text { Time (RT) }\end{array}$ & Mass & Name & Molecular formula \\
\hline 1 & 1.433 & 174.1127 & D-Arginine & $\mathrm{C}_{6} \mathrm{H}_{14} \mathrm{~N}_{4} \mathrm{O}_{2}$ \\
\hline 2 & 1.761 & 224.188 & 1,3-Dicyclohexylurea & $\mathrm{C}_{13} \mathrm{H}_{24} \mathrm{~N}_{2} \mathrm{O}$ \\
\hline 3 & 1.801 & 155.0591 & Ethosuximide M5 & $\mathrm{C}_{7} \mathrm{H}_{9} \mathrm{NO}_{3}$ \\
\hline 4 & 1.854 & 342.118 & Maltose & $\mathrm{C}_{12} \mathrm{H}_{22} \mathrm{O}_{11}$ \\
\hline 5 & 1.868 & 162.114 & Carnitine & $\mathrm{C}_{7} \mathrm{H}_{16} \mathrm{NO}_{3}$ \\
\hline 6 & 2.399 & 290.1364 & Trimethoprim & $\mathrm{C}_{14} \mathrm{H}_{18} \mathrm{~N}_{4} \mathrm{O}_{3}$ \\
\hline 7 & 2.4 & 225.0857 & Acyclovir & $\mathrm{C}_{8} \mathrm{H}_{11} \mathrm{~N}_{5} \mathrm{O}_{3}$ \\
\hline 8 & 2.426 & 267.0968 & 3-Deoxyguanosine & $\mathrm{C}_{10} \mathrm{H}_{13} \mathrm{~N}_{5} \mathrm{O}_{4}$ \\
\hline 9 & 2.927 & 147.0542 & O-Acetylserine & $\mathrm{C}_{5} \mathrm{H}_{9} \mathrm{NO}_{4}$ \\
\hline 10 & 5.92 & 148.0744 & Pantoic acid & $\mathrm{C}_{6} \mathrm{H}_{12} \mathrm{O}_{4}$ \\
\hline 11 & 5.922 & 332.1106 & Pro Asn Cys & $\mathrm{C}_{12} \mathrm{H}_{20} \mathrm{~N}_{4} \mathrm{O}_{5} \mathrm{~S}$ \\
\hline 12 & 5.923 & 327.1544 & Ala His Thr & $\mathrm{C}_{13} \mathrm{H}_{21} \mathrm{~N}_{5} \mathrm{O}_{5}$ \\
\hline 13 & 5.923 & 288.1457 & $\mathrm{~N}$-(3-Indolylacetyl)-Lisoleucine & $\mathrm{C}_{16} \mathrm{H}_{20} \mathrm{~N}_{2} \mathrm{O}_{3}$ \\
\hline 14 & 6.299 & 459.1433 & Moricizine sulfone & $\mathrm{C}_{22} \mathrm{H}_{25} \mathrm{~N}_{3} \mathrm{O}_{6} \mathrm{~S}$ \\
\hline 15 & 6.421 & 346.1255 & Aucubin & $\mathrm{C}_{15} \mathrm{H}_{22} \mathrm{O}_{9}$ \\
\hline 16 & 6.485 & 401.1604 & Tyr Gly Tyr & $\mathrm{C}_{20} \mathrm{H}_{23} \mathrm{~N}_{3} \mathrm{O}_{6}$ \\
\hline 17 & 6.608 & 401.1622 & $\begin{array}{c}\text { Meropenem Metabolite (2HPyrrole-2-acetic } \\
\text { acid, 5-carboxy-4-[[(3S,5S)-5-[(dimethylamino) } \\
\text { carbonyl]-3- }\end{array}$ & $\mathrm{C}_{17} \mathrm{H}_{27} \mathrm{~N}_{3} \mathrm{O}_{6} \mathrm{~S}$ \\
\hline 18 & 6.94 & 306.133 & Trimethoprim 1-N-oxide & $\mathrm{C}_{14} \mathrm{H}_{18} \mathrm{~N}_{4} \mathrm{O}_{4}$ \\
\hline 19 & 6.962 & 418.1866 & Asp Val Trp & $\mathrm{C}_{20} \mathrm{H}_{26} \mathrm{~N}_{4} \mathrm{O}_{6}$ \\
\hline 20 & 7.103 & 184.0383 & Everninic Acid & $\mathrm{C}_{8} \mathrm{H}_{8} \mathrm{O}_{5}$ \\
\hline 21 & 7.133 & 387.2491 & Lys GIn Leu & $\mathrm{C}_{17} \mathrm{H}_{33} \mathrm{~N}_{5} \mathrm{O}_{5}$ \\
\hline 22 & 7.237 & 286.1095 & His Met & $\mathrm{C}_{11} \mathrm{H}_{18} \mathrm{~N}_{4} \mathrm{O}_{3} \mathrm{~S}$ \\
\hline 23 & 7.241 & 156.0431 & Iretol & $\mathrm{C} 7 \mathrm{H} 8 \mathrm{O} 4$ \\
\hline 24 & 7.262 & 398.1266 & Cys Tyr Asn & $\mathrm{C}_{16} \mathrm{H}_{22} \mathrm{~N}_{4} \mathrm{O}_{6} \mathrm{~S}$ \\
\hline 25 & 7.321 & 449.2861 & Gentamicin C1a & $\mathrm{C}_{19} \mathrm{H}_{39} \mathrm{~N}_{5} \mathrm{O}_{7}$ \\
\hline 26 & 7.368 & 168.043 & Vanillic acid & $\mathrm{C}_{8} \mathrm{H}_{8} \mathrm{O}_{4}$ \\
\hline 27 & 7.479 & 475.3021 & Netilmicin & $\mathrm{C}_{21} \mathrm{H}_{41} \mathrm{~N}_{5} \mathrm{O}_{7}$ \\
\hline 28 & 7.522 & 188.0695 & Ethyl Oxalacetate & $\mathrm{C}_{8} \mathrm{H}_{12} \mathrm{O}_{5}$ \\
\hline 29 & 7.535 & 324.2093 & 9a-Fluoro-Bhydroxyandrosterone & $\mathrm{C}_{19} \mathrm{H}_{29} \mathrm{FO}_{3}$ \\
\hline 30 & 7.62 & 538.3471 & GPCho(16:0/2:0[U]) & $\mathrm{C}_{26} \mathrm{H}_{53} \mathrm{NO}_{8} \mathrm{P}$ \\
\hline 31 & 7.744 & 564.3627 & GPCho(18:1(9Z)/2:0[U]) & $\mathrm{C}_{28} \mathrm{H}_{55} \mathrm{NO}_{8} \mathrm{P}$ \\
\hline 32 & 8.226 & 320.0546 & Dihydromyricetin & $\mathrm{C}_{15} \mathrm{H}_{12} \mathrm{O}_{8}$ \\
\hline 33 & 8.435 & 342.2321 & Val Lys Pro & $\mathrm{C}_{16} \mathrm{H}_{30} \mathrm{~N}_{4} \mathrm{O}_{4}$ \\
\hline 34 & 8.711 & 448.1028 & Quercitrin & $\mathrm{C}_{21} \mathrm{H}_{20} \mathrm{O}_{11}$ \\
\hline 35 & 9.639 & 273.2681 & C16 Sphinganine & $\mathrm{C}_{16} \mathrm{H}_{35} \mathrm{NO}_{2}$ \\
\hline 36 & 9.736 & 287.2838 & C17 Sphinganine & $\mathrm{C}_{17} \mathrm{H}_{37} \mathrm{NO}_{2}$ \\
\hline 37 & 10.186 & 264.0678 & Sulfamerazine & $\mathrm{C}_{11} \mathrm{H}_{12} \mathrm{~N}_{4} \mathrm{O}_{2} \mathrm{~S}$ \\
\hline 38 & 11.127 & 318.075 & Lecanoric acid & $\mathrm{C}_{16} \mathrm{H}_{14} \mathrm{O}_{7}$ \\
\hline 39 & 11.375 & 180.0428 & Acetylsalicylic acid (aspirin) & $\mathrm{C}_{9} \mathrm{H}_{8} \mathrm{O}_{4}$ \\
\hline 40 & 11.398 & 567.2931 & Dihydrodeoxystreptomycin & $\mathrm{C}_{21} \mathrm{H}_{41} \mathrm{~N}_{7} \mathrm{O}_{11}$ \\
\hline 41 & 11.398 & 568.2773 & Leukotriene F4 & $\mathrm{C}_{28} \mathrm{H}_{44} \mathrm{~N}_{2} \mathrm{O}_{8} \mathrm{~S}$ \\
\hline 42 & 11.574 & 284.333 & Cetrimonium & $\mathrm{C}_{19} \mathrm{H}_{42} \mathrm{~N}$ \\
\hline 43 & 11.663 & 190.0272 & 3-(trifluoromethyl)-Benzoic acid & $\mathrm{C}_{8} \mathrm{H}_{5} \mathrm{~F}_{3} \mathrm{O}_{2}$ \\
\hline
\end{tabular}




\begin{tabular}{|c|c|c|c|c|}
\hline 44 & 13.308 & 308.1894 & $\begin{array}{l}\text { 2-Pyrrolidinone, 4-(2-aminoethyl)-1-ethyl-3,3- } \\
\text { diphenyl- (AHR 5904) }\end{array}$ & $\mathrm{C}_{20} \mathrm{H}_{24} \mathrm{~N}_{2} \mathrm{O}$ \\
\hline 45 & 13.311 & 329.1633 & Sinomenine & $\mathrm{C}_{19} \mathrm{H}_{23} \mathrm{NO}_{4}$ \\
\hline 46 & 14.652 & 224.1422 & Methyl jasmonate & $\mathrm{C}_{13} \mathrm{H}_{20} \mathrm{O}_{3}$ \\
\hline 47 & 15.139 & 199.1952 & Dodecanamide & $\mathrm{C}_{12} \mathrm{H}_{25} \mathrm{NO}$ \\
\hline 48 & 15.826 & 252.1737 & Punctaporin B & $\mathrm{C}_{15} \mathrm{H}_{24} \mathrm{O}_{3}$ \\
\hline 49 & 15.903 & 594.4254 & GPCho(11:0/11:0[U]) & $\mathrm{C}_{30} \mathrm{H}_{61} \mathrm{NO}_{8} \mathrm{P}$ \\
\hline 50 & 15.982 & 550.3988 & GPCho(O-18:1(9Z)/2:0[S]) & $\mathrm{C}_{28} \mathrm{H}_{57} \mathrm{NO}_{7} \mathrm{P}$ \\
\hline 51 & 16.114 & 426.3008 & Leupeptin & $\mathrm{C}_{20} \mathrm{H}_{38} \mathrm{~N}_{6} \mathrm{O}_{4}$ \\
\hline 52 & 16.601 & 318.1461 & Zearalenone & $\mathrm{C}_{18} \mathrm{H}_{22} \mathrm{O}_{5}$ \\
\hline 53 & 17.13 & 375.9845 & Ambroxol & $\mathrm{C}_{13} \mathrm{H}_{18} \mathrm{Br}_{2} \mathrm{~N}_{2} \mathrm{O}$ \\
\hline 54 & 17.695 & 297.2683 & (Z)-N-(2-hydroxyethyl)hexadec-7-enamide & $\mathrm{C}_{18} \mathrm{H}_{35} \mathrm{NO}_{2}$ \\
\hline 55 & 18.391 & 464.3139 & $\begin{array}{l}\text { 3alpha,6alpha,7alpha,12alpha-Tetrahydroxy- } \\
\text { 5betacholest-24-en-26-oic acid }\end{array}$ & $\mathrm{C}_{27} \mathrm{H}_{44} \mathrm{O}_{6}$ \\
\hline 56 & 19.049 & 504.3461 & Madecassic Acid & $\mathrm{C}_{30} \mathrm{H}_{48} \mathrm{O}_{6}$ \\
\hline 57 & 19.091 & 299.2848 & $\mathrm{~N}$-(2-hydroxyethyl)palmitamide & $\mathrm{C}_{18} \mathrm{H}_{37} \mathrm{NO}_{2}$ \\
\hline 58 & 19.234 & 566.383 & $\begin{array}{l}\text { (5b,12a), 9-anthracenylmethyl ester, 12-hydroxy- } \\
\text { Cholan-24-oic acid }\end{array}$ & $\mathrm{C}_{39} \mathrm{H}_{50} \mathrm{O}_{3}$ \\
\hline 59 & 19.29 & 460.3197 & $\begin{array}{l}\text { 1alpha,24,25,28-tetrahydroxyvitamin D2 } \\
\text { /1alpha,24,25,28-tetrahydroxyergocalciferol }\end{array}$ & $\mathrm{C}_{28} \mathrm{H}_{4} 4 \mathrm{O}_{5}$ \\
\hline 60 & 22.233 & 606.2895 & Trandolapril glucuronide & $\mathrm{C}_{30} \mathrm{H}_{42} \mathrm{~N}_{2} \mathrm{O}_{11}$ \\
\hline 61 & 23.999 & 430.2718 & 17-phenyl-trinor-PGF2alphaisopropyl ester & $\mathrm{C}_{26} \mathrm{H}_{38} \mathrm{O}_{5}$ \\
\hline 62 & 26.409 & 152.1083 & (3-Hydroxyphenyl)trimethylamm & $\mathrm{C}_{9} \mathrm{H}_{14} \mathrm{NO}$ \\
\hline 63 & 26.414 & 166.1236 & Edrophonium & $\mathrm{C}_{10} \mathrm{H}_{16} \mathrm{NO}$ \\
\hline
\end{tabular}

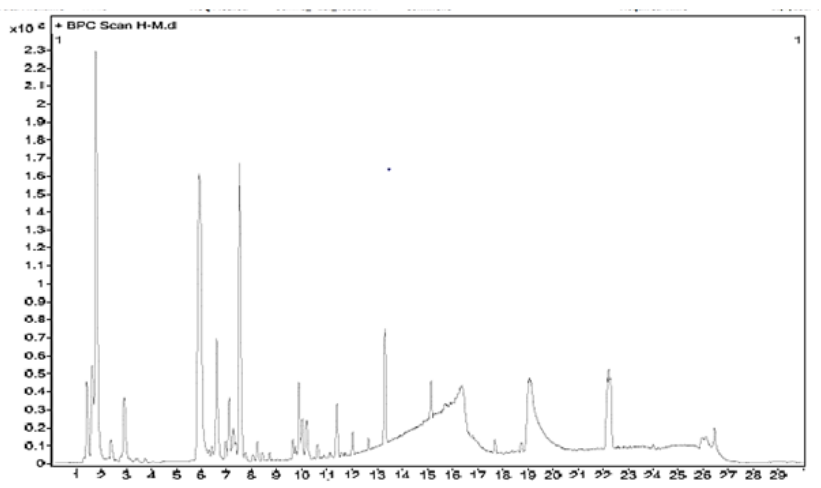

\section{Supplementary Figure 1: Chromatogram of MELIS obtained from HR-LC/Q-TOF/MS.}




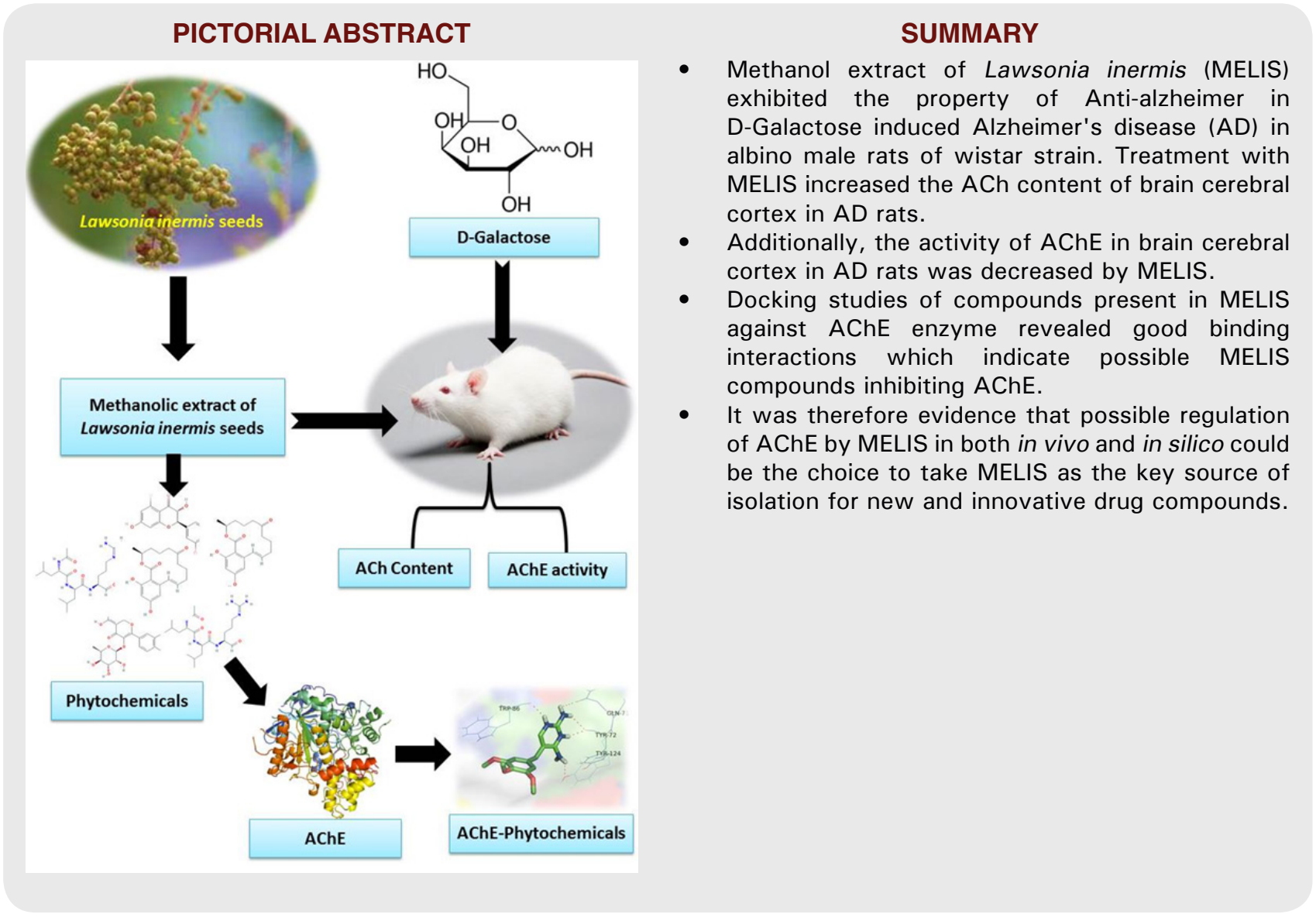

Cite this article: Jyothi P, Yellamma K. Anti-Alzheimer's Activity of Compounds from the Methanolic Extract of Lawsonia inermis Seeds: In vivo and in silico Molecular Docking Studies. Indian J of Pharmaceutical Education and Research. 2021;55(2):463-73. 